\title{
A critical analysis of Talent Management in German small and medium-sized companies (SMES) Part II
}

\author{
Matthias Bender ${ }^{1}$ \\ Comenius University, Faculty of Management, Bratislava, Slowakia
}

\begin{abstract}
The article aims to determine which aspects need to be considered to operate effective and efficient talent management.

Three hypotheses were formulated, which were processed with qualitative content analysis. The investigation was performed using the software MaxQDA.

The following aspects have been identified as critical pillars for successful talent management:

- The process of talent management must be implemented holistically.

- It must be clear which positions in the company contribute in a particular way to the company's success and what requirements the personnel intended for this purpose must meet.

- Talent management should play its part both in times of recovery and in times of crisis to

- Always ensure the consistent availability of mission-critical workers.

○ take advantage of the crisis to prepare for an expansion starting at the beginning of the recovery.

Employer branding is an aspect that should also be considered in the context of talent management.
\end{abstract}

Keywords: Talent Management, Key Function, identify and win, assessment and insertion, Talent development, motivation and binding

JEL Classification: M12, M50

\footnotetext{
${ }^{1}$ Doctoral supervisor: Prof. Ing. Lubica Bajzikova, Comenius University, Faculty of Management, Bratislava, Slovakia
} 


\section{Introduction}

In principle, after the 2008 financial crisis, economic development was characterized by sustained growth, impacting the labor market. The demand for employees has increased as well. In addition to this positive development, other factors have a significant impact on staff availability. „Demographic change, transparency through the Internet, brain drain, changes in the requirements of the world of work, the educational landscape that is not quite set up according to needs, and a change in communication behavior are framework conditions that are sustainable and that are difficult to ignore "(Bender, 2021, p. 129). These conditions were optimal for the employee side, as qualified personnel could almost choose the employer.

As a result of the Corona pandemic, the economy and social life had to be temporarily shut down. This lockdown has had and has a massive impact on employees. At the Employment Agency, companies reported a short time working for some 10.6 million workers. This is 31.4 percent of the employees subject to social security contributions in Germany. Besides, the unemployment rate rose to a moderate $6.1 \%$ between March and May (cf. Seil \& Emmler, 2020, p. 2).

In a special report of March 2020, various scenarios were discussed in this regard. If the economic recovery due to the pandemic does not start until 2021, it is possible that the measures taken will not be sufficient and that companies will have to lay off employees (cf. Feld, Truger, \& Wieland, 2020, p. 2).

The considerations made in March have come true in the meantime. For example, the following table summarizes some reports of redundancies from well-known companies (see Table 1):

Table 1 Extractable scan of announced redundancies in 2020

\begin{tabular}{|l|l|l|l|}
\hline Company & $\begin{array}{l}\text { Notification } \\
\text { from the }\end{array}$ & $\begin{array}{l}\text { Number of } \\
\text { redundancies }\end{array}$ & Source \\
\hline Lufthansa AG & 06.08 .2020 & 22000 & $\begin{array}{l}\text { https://www.tagesschau.de/wirtschaft/lufthansa- } \\
\text { stellenabbau-101.html }\end{array}$ \\
\hline $\begin{array}{l}\text { Daimler } \\
\text { AG }\end{array}$ & 17.07 .2020 & 20000 & $\begin{array}{l}\text { https://www.bw24.de/stuttgart/daimler-ag- } \\
\text { mercedes-benz-stuttgart-global-stellenabbau- } \\
\text { verluste-personal-beschaeftigte-coronavirus-krise- } \\
\text { zukunft-90010648.html }\end{array}$ \\
\hline $\begin{array}{l}\text { BMW } \\
\text { AG }\end{array}$ & 19.06 .2020 & 6000 & $\begin{array}{l}\text { https://www.tagesschau.de/wirtschaft/bmw- } \\
\text { stellenabbau-101.html }\end{array}$ \\
\hline $\begin{array}{l}\text { Continental } \\
\text { AG }\end{array}$ & 15.09 .2020 & 1800 & $\begin{array}{l}\text { https://www.wz.de/wirtschaft/continental-will- } \\
\text { weiteres-werk-schliessen_aid-53369455 }\end{array}$ \\
\hline $\begin{array}{l}\text { Commerzbank } \\
\text { homm-28.01-2021 }\end{array}$ & 10000 & $\begin{array}{l}\text { https://www.n-tv.de/wirtschaft/Commerzbank- } \\
\text { streicht-10-000-Stellen-article22323492.html }\end{array}$ \\
\hline
\end{tabular}

Source: own depiction

Even if the economic situation described just now is opposed, both scenarios, crisis and upswing, have something in common. As a company, you must make the right staff (talents) available in both scenarios.

This article continues the investigations initiated in the first (cf. Bender, 2021), adapted to the findings and considerations made there (cf. chapter 2). Chapter 3 explains in detail the methodological approach to identifying the pillars of talent management. Chapter 4 summarises the results of the investigation and discusses them in Chapter 5. 


\section{Theoretical Background}

Chapter 2 is intended first to reflect the previous article's key messages (cf. Bender, 2021). The economic crisis in terms of talent management has not played a role yet. This aspect is explained in the second step. In a third step, selection criteria will be developed, according to which the industry to be examined can be determined. These two aspects are finally considered as to whether they influence the research question or on the hypotheses formulated so far.

\subsection{Key statements of the previous article}

The previous study has shown that there are many literature approaches to define talent and talent management. It is not surprising that no general statements can be derived, as many of the existing analyses often focus on individual companies. Therefore, it is even more critical to determine whether a consensus can be established when the companies studied belong to one industry.

Considerations and findings have led to the fact that a workers' market has emerged because of the long-term and positive economic development and that companies must fight for their employees.

It was possible to answer who is needed to implement talent management in the company successfully. Formal corporate structures are necessary, close to corporate governance that talent management really wants. What and how to implement talent management is to be identified in this article (cf. Bender, 2021).

\subsection{Economic phases and forms of crisis}

Germany and the world are in a pandemic crisis that has also had a massive impact on the economy. But a crisis is part of an economic cycle. The economic development of an economy consists of four different economic phases (see Figure 1):

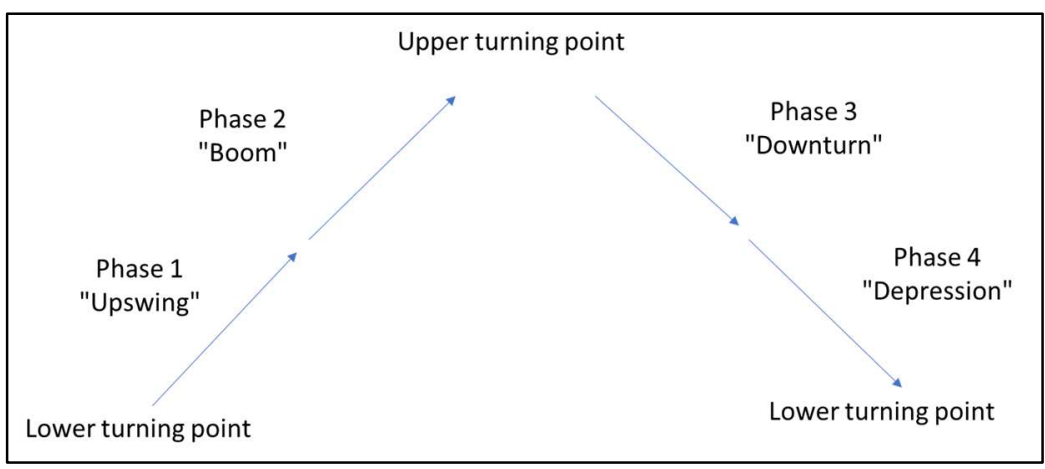

Figure 1 Economic phases (cf. Horn, 2020)

Source: own depiction

While the economy is growing in phases 1 and 2, the economy is shrinking in phases 3 and 4. This negative development in phases 3 and 4 means that personnel release is also possible (cf. Horn, 2020).

The key question for any further action is how long this depression lasts. On 25.05.2020, tagesschau.de reported there are various assumptions about the course of the Corona Pandemic. There are representatives for each of the four variants - V, U, W, and L - (see Figure 2) who expect this or that development: 


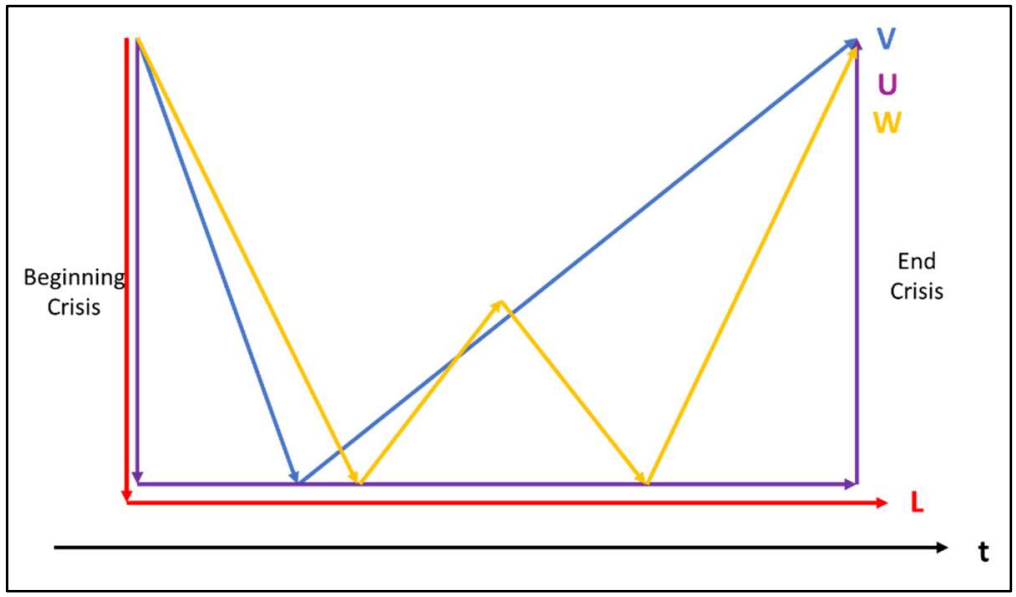

Figure 2 Possible crisis histories Source: own depiction

The most favorable option for the economy is the V-shaped development. After a burglary, a quick recovery takes place. The U-, $\mathrm{W}$ - and L-shaped developments are significantly less favorable (cf. tagesschau.de, 2020).

\subsection{Industries, talent forgeries, and existing companies}

The aim is to identify an industry in which the concept of talent and the process of talent management is to be further investigated. As a prerequisite, the industry should be comparatively stable. Consistency is understood here as workplaces with a rarely necessary for change (cf. Ziegler, Hefler, Markowitsch, \& Lehner, 2010, p. 47). For this purpose, the following sub-chapter first deals with the industries and then the appropriate talent forgeries, universities, or vocational training institutions.

\section{Industries:}

On the Internet, you can find various industry overviews, which are similarly structured. On the webpage "Economic Forum" (https://www.wirtschaftsforum.de/branchen/), 19 industries are listed, whereas on the web page "kununu" (https://www.kununu.com/de/branchen) 42 industries are listed. At first glance, however, these two options do not offer any further breakdown, whereas the "Statistical Classification of Economic Activities in the European Community" (NACE) (https://ec.europa.eu/eurostat/documents/3859598/5902453/KS-RA-07-015-

DE.PDF) is too detailed. The webpage of "Statista", on the other hand, offers a further differentiation without getting too complicated. Table 2 is summarizing the respective industries with the corresponding subdivisions (numerically): 
Table 2 Industry overview (cf. STATISTA, 2020)

\begin{tabular}{|c|c|c|c|}
\hline Industry & AGRICULTURE & CONSTRUCTION & $\begin{array}{c}\text { CHEMISTRY \& RAW } \\
\text { MATERIALS }\end{array}$ \\
\hline Segments & 3 & 2 & 7 \\
\hline Industry & SERVICE \& CRAFTS & $\begin{array}{c}\text { E-COMMERCE \& } \\
\text { DISTRIBUTION }\end{array}$ & $\begin{array}{c}\text { ENERGY \& } \\
\text { ENVIRONMENT }\end{array}$ \\
\hline Segments & 3 & 4 & 5 \\
\hline Industry & FINANCE, INSURANCE \& REAL & LEISURE & SOCIETY \\
\hline Segments & 4 & 6 & 8 \\
\hline Industry & TRADE & INTERNET & KONSUM \& FMCG \\
\hline Segments & 11 & 8 & METAL \& \\
\hline Industry & LIFE & MEDIA \& MARKETING & 8 \\
\hline Segments & 4 & 5 & TLECTRONICS \\
\hline Industry & PHARMA \& HEALTH & TECHNOLOGY \& & GASTRONOMY \\
\hline Segments & 6 & 7 & 5 \\
\hline Industry & TRANSPORT \& LOGISTICS & ADMINISTRATION \& & ECONOMY \& \\
& & DEFENITICS
\end{tabular}

Source: own depiction

A final determination cannot yet be made since the degree of abstraction is still too great. All sectors with more than three subdivisions have been excluded due to the complexity of the industry. Although SERVICE \& CRAFTS and ADMINISTRATION \& DEFENSE have this criterion, both industries have been excluded, as there is also a great complexity here. The AGRICULTURE and CONSTRUCTION industries will be examined for the next step in studying the talent forgeries.

\section{Talent forging:}

To be prepared for working life, there is the possibility of dual training, school vocational training, and study in Germany (cf. Bundesagentur, 2020). An evaluation of vocational training was not initially followed up, as this approach has proved impractical (cf. Bildungsserver, 2020).

On the webpage "Studis online" the following fields of study are distinguished: Law and Economics, Administration; Teaching posts; Engineering, Mathematics, Computer Science; Science; Social sciences; Media and communication; Medicine, Healthcare, Sports; Music, art, and design; Linguistic and Cultural Studies; Agricultural and forestry sciences (cf. Iost \& Iost, 2020). This partition proved appropriate for the corresponding industries AGRICULTURE and CONSTRUCTION with agricultural/ forestry sciences and Engineering/ Mathematics/ Computer Science studies.

With the help of the webpage "Studis online" the various fields of study were investigated. The search terms with the numerical hits can be found in Table 3: 
Table 3 Excerpt's overview of study offers

\begin{tabular}{|c|c|}
\hline Keyword & Programs \\
\hline Fisheries & 8 \\
\hline Wine & 18 \\
\hline Forestry & 30 \\
\hline Agriculture & 89 \\
\hline Civil engineering & 250 \\
\hline Construction management & 59 \\
\hline Construction Technology & 33 \\
\hline
\end{tabular}

Source: own depiction

As the construction industry is also too broad, the subjects' agricultural and forestry sciences were examined more. The study opportunities for brewing and beverage technology were identified. There are 13 courses of study that are taught at five universities (cf. Iost \& Iost, 2020):

Table 4 Overview of study opportunities in the field of brewing and beverage technology

\begin{tabular}{|c|c|c|}
\hline University & Field of study & Study description \\
\hline $\begin{array}{l}\text { Justus-Liebig- } \\
\text { Universität } \\
\text { Gießen }\end{array}$ & Beverage technology (M.SC.) & $\begin{array}{c}\text { https://www.uni- } \\
\text { giessen.de/studium/studienangebot/master/getr } \\
\text { aenketechnologie }\end{array}$ \\
\hline $\begin{array}{l}\text { Hochschule } \\
\text { Geisen-heim } \\
\text { University } \\
\end{array}$ & Beverage technology (M.SC.) & $\begin{array}{c}\text { https://www.hs- } \\
\text { geisenheim.de/index.php?id=178 }\end{array}$ \\
\hline $\begin{array}{l}\text { Technische } \\
\text { Universität } \\
\text { München }\end{array}$ & $\begin{array}{c}\text { Brewing (Diplom- Braumeister) } \\
\text { Brewing and beverage } \\
\text { technology (M.SC.) }\end{array}$ & $\begin{array}{c}\text { https://www.tum.de/studium/studienangebot/d } \\
\text { etail/brauwesen-abschluss-diplombraumeister- } \\
\text { diplom-braumeister/ } \\
\text { https://www.tum.de/studium/studienangebot/d } \\
\text { etail/brauwesen-und-getraenketechnologie- } \\
\text { master-of-science-msc/ }\end{array}$ \\
\hline $\begin{array}{l}\text { Hochschule } \\
\text { Weihenstephan } \\
\text {-Triesdorf } \\
\end{array}$ & $\begin{array}{l}\text { Brewing and beverage } \\
\text { technology (B. Eng) }\end{array}$ & $\begin{array}{c}\text { https://www.hswt.de/studium/studiengaenge/b } \\
\text { g.html }\end{array}$ \\
\hline $\begin{array}{l}\text { Technische } \\
\text { Universität } \\
\text { Berlin }\end{array}$ & $\begin{array}{l}\text { Brewery and Beverage } \\
\text { Technology (M.SC.) }\end{array}$ & $\begin{array}{l}\text { https://www.tu.berlin/studieren/studienangebot } \\
\text { /gesamtes- } \\
\text { studienangebot/studiengang/brauerei-und- } \\
\text { getraenketechnologie-m-sc/ }\end{array}$ \\
\hline
\end{tabular}

Source: own depiction

\section{Existing companies:}

According to the German Brewers Association, there were 1.539 breweries in Germany in 2018. Of these, 654 are in Bavaria, 206 in Baden-Württemberg, and 155 in North RhineWestphalia (cf. Brauerbund, 2020). Comparing to 3.483.691 companies (cf. STATISTA, 2020), which existed in Germany in 2018, this is a share of $0.04 \%$.

\subsection{Assessment of points 2.1 to 2.3}

Due to the current development, talent management cannot be examined solely because the economic conditions are consistently positive. Large companies have announced that 
they will be exhibiting staff. It would be more than naive if one were to assume that SMEs would be spared this development.

Due to the comparatively manageable size and the relatively small number of training institutions (universities), the brewing industry should be an excellent opportunity further to investigate the process of talent management in this environment.

\subsection{Conclusions}

The following questions can be derived from the assessments made in 2.4:

Does the entire economic situation, upswing, or crisis have an impact on the talent management process?

What is the whole situation in the brewing industry?

The aspect of the crisis must be considered and dealt with in further processing. However, due to the formulated research question's objective, it makes no sense to deepen the brewing industry's focus in this research.

\section{Methods}

Until now, the formulated research question has only been considered under the framework conditions of economic recovery. Since this is not always the case, talent management is to be investigated in addition to times of crisis. The research question itself does not need to be reworded and will be maintained: Which pillars are there on which effective and efficient talent management is based? For answering the formulated research question, in conclusion, the pending hypotheses are to be examined below:

H3) The smaller an enterprise, the more it is true that the owner's position is the key position.

H4) If talent management is implemented holistically, it can only contribute to the company's success.

H5) When a company is in an economic crisis, talent management is no longer necessary.

Here, too, what was already stated in the previous article applies. It is not a question of establishing that the owner of an SME has a key function. It is a vehicle to deal with the topic.

Detailed literature research was carried out as a basis to be able to carry out a qualitative literature analysis based on this (cf. Mayring, 2015, p. 50 ff)) for confirming or rejecting these hypotheses. The following scientific databases were used for the literature search:

a) Google Search

b) Google Scholar

c) SCOPUS

d) Springer Link

e) EBSCO Host 


\section{f) ECONBiz}

The literature search was carried out mainly with the help of the database f) ECONBiz. In Table 5, the possible sources for the related search terms were recorded numerically. The query was based on the previous act's data and is not displayed again at this point (cf. Bender, 2021, p. 133):

Table 5 Numerical results overview of the literature search with the database ECONBiz

\begin{tabular}{|l|l|l|l|l|l|}
\hline Keyword $^{2}$ & Results & Containment & Results & Containment & Results \\
\hline Talent management in crisis & 8 & In Germany & 4 & $\begin{array}{l}\text { Since 2008 - 2011 } \\
\text { And in 2020 }\end{array}$ & $\begin{array}{l}1 \\
0\end{array}$ \\
\hline $\begin{array}{l}\text { Human resources } \\
\text { management in crisis }\end{array}$ & 242 & In Germany & 171 & $\begin{array}{l}\text { Since 2008 - 2011 } \\
\text { And in 2020 }\end{array}$ & $\begin{array}{l}35 \\
0\end{array}$ \\
\hline Economic crisis & 17939 & In Germany & 2005 & $\begin{array}{l}\text { Since 2008 - 2011 } \\
\text { And in 2020 }\end{array}$ & $\begin{array}{l}813 \\
59\end{array}$ \\
\hline Retrenchment & 1555 & In Germany & 562 & $\begin{array}{l}\text { Since 2008 - 2011 } \\
\text { And in 2020 }\end{array}$ & $\begin{array}{l}86 \\
1\end{array}$ \\
\hline
\end{tabular}

Source: Own Representation

Based on the literature research, 2742 possible sources were initially identified with the restriction "In Germany". Depending on the keyword, the hit results were evaluated by further selection criteria and condensed into 995 potential sources, of which 87 documents were finally considered relevant, which also have the appropriate quality. Ultimately, 25 sources were used for this article. The publications of the sources ranged from 2001 to 2021.

The selected literature was examined with the MAXQDA software, using 6 main codes and 14 subcodes summarized in Figure 3. The qualitative content analysis was deductive and has been derived from definitions and findings of the theoretical background (cf. Bender, 2021, p. $129 \mathrm{ff}$ and Chapter 2). In the selected literature, these words were searched using the "lexical search" function, autocoded, and then evaluated for usability (structured content analysis).

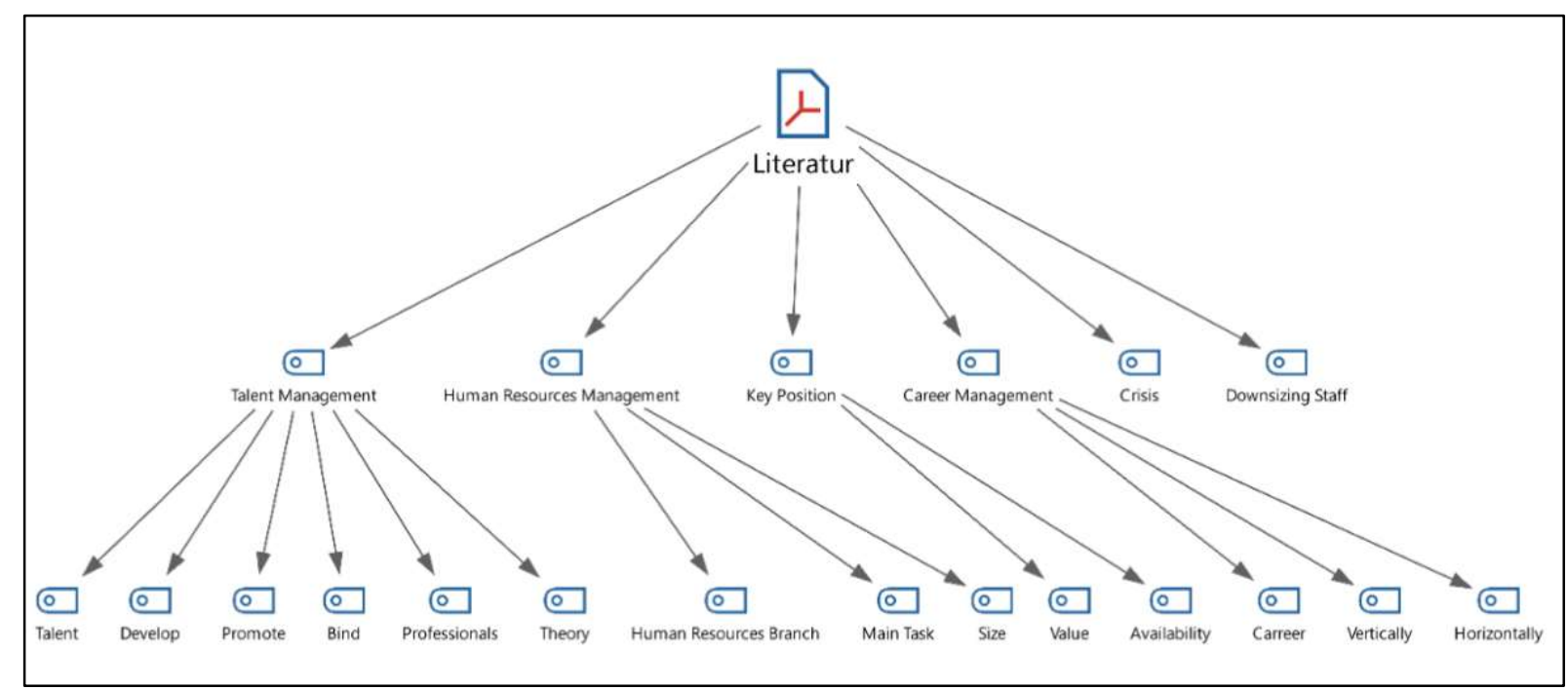

\footnotetext{
2 The query was carried out using the German terms: Talentmanagement in der Krise, Personalmanagement in der Krise, Wirtschaftskrise, Personalabbau; Query on 26.10.2020
} 


\section{Research results}

\subsection{Results for H3: The smaller the company, the more likely it is that the owner's position is the key position.}

There are different approaches in the literature defining the value of a person or group of people for a company. In his remarks, Ridder states that the employees' totality can be classified according to the parameter's "value" and "uniqueness". This results in a portfolio of 4 fields (see Figure 06). Although the employee assigned to the third quadrant has less value and less uniqueness for the company, this does not mean that the company can do without this group of people. It just means that the group should be treated according to their status (cf. Ridder, 2001, p. 103 ff)).

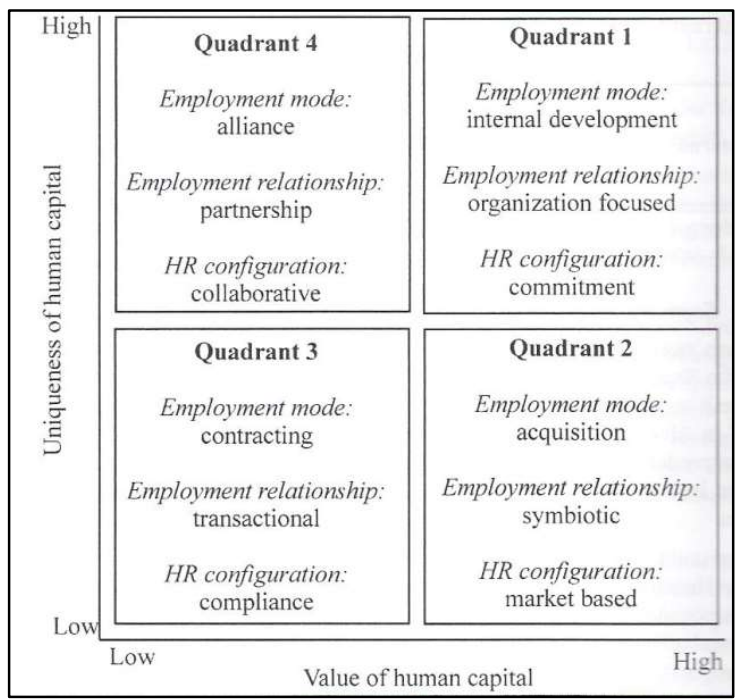

Figure 2 Value and uniqueness Portfolio

Source: Ridder, 2001, p. 104

Süßmuth also demands that critical workers must be identified if a company should be successful. He defines more precisely what characteristics must be met for these employees to impact the company's success. As an employee, one is particularly valuable if one influences the company's strategy in one's function, and/ or is essential for the core business, and/ or needs in the labor market, and/ or has valuable knowledge about the industry. If there is a high supply of workers for corresponding functions and/ or if any vacancies occur, they have no impact on the company's success. One belongs to a less important group of employees (cf. Süßmuth, 2009, p. 65 f)).

One group that influences the company's success is executives. In her essay, Weitz described the talent management of two medium-sized companies, size 102 and 250 employees, who wanted to generate the necessary junior managers internally, explicitly through this process. Unfortunately, in this example, the companies were only partially successful (cf. Weitz, 2009, p. 68 ff)). Other authors also determine the fact that managers 
have particular importance (cf. Boudreau \& Ramstad, 2005, p. 22); (Ziegler, Hefler, Markowitsch, \& Lehner, 2010, p. 50); (Cappelli \& Keller, 2014, p. 308 f)

Trost notes in his remarks that there are "bottleneck functions" and "key functions". A "bottleneck" function exists when the required number of employees is difficult to cover. A "key function" exists if this function is of strategic importance to the company. Nathan Myhrvold, former Chief Technology Officer at Microsoft, made the following statement: "The top software developers are more productive than average software developers not by a factor of 10 or 100, or even 1000, but 10000" (cf. Trost, 2012, p. 26 f). Trost has illustrated the context just described in the following figure (see Figure 07):

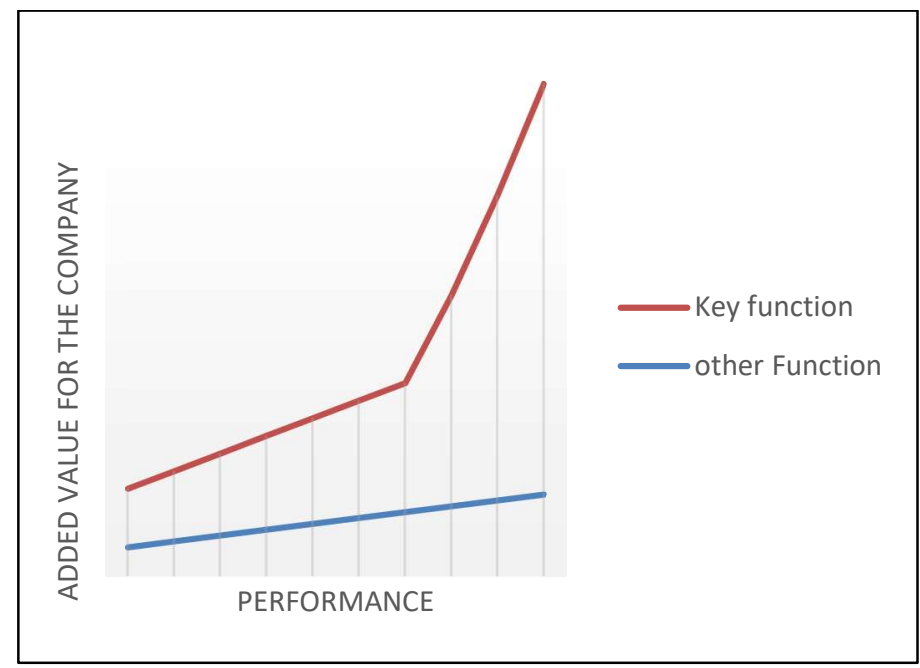

Figure 3 Relationship between performance and added value for key functions and other functions Source: see Trost, 2012, p. 28 (translated)

If this differentiation is applied, for example, to a company in the IT sector, the logistics specialist, which is also needed in an IT company, would be an "other function" (blue line). In contrast, the computer scientist would have a "key function" (red line) if the computer scientist had the appropriate skills to deliver product innovations to increase its added value significantly. And for these key function(s), the necessary talent(s) are to be made available with talent management. According to Whysall et al. the focus shifted from "identifying „A performers" to one on the „identification“ of key positions which have the potential to differentially impact on sustainable competitive advantage" (Whysall, Owtram, \& Brittain, 2019, p. 119).

\subsection{Results on H4: If talent management is implemented holistically, it can only contribute to the company's success.}

The first to illustrate the importance of this hypothesis is to be presented through an example from practice. An entrepreneur from the Bavarian construction industry has paid some of his workers the driver's license for trucks with trailers. The better-qualified workers then applied to competitive companies, found a job there, and with a higher salary due to higher qualifications. What mistake did the entrepreneur make at this point? He has implemented a stand-alone personnel development measure (paying the training for a driving license) without having set it in an overall concept (keywords: "identify and 
win", "assessment and insertion", "development", and "motivation and binding" (cf. Ewerlin, 2013, p. 21f).

Burger concludes that talent management can only work if there is a basic system in the company and is not based on various stand-alone measures. It must be clear to all stakeholders that talent management is necessary for the company's success, that it must be consistently implemented and always communicated (cf. Burger, 2009, p. 66 f)). Ewerlin also determined the relevance of appropriate communication (cf. Ewerlin, 2013, p. 154).

Different authors explicitly point out that talent management is to be located at a strategic level in literature. Furthermore, the overall process consists of several steps (cf. Schaper, 2009, p. 24 ff; Weitz, 2009, p. 68 f; Ritz \& Sinelli, 2010, p. 11; Trost, 2014, p. 258 f). For Industry 4.0, for example, this has been formulated as follows: "Industry 4.0 requires a broader and more holistic talent management solution than simply plugging talent gaps through more intensive lateral hiring" (Whysall, Owtram, \& Brittain, 2019, p. 119). One way for a holistic talent management concept is shown in Figure 08:

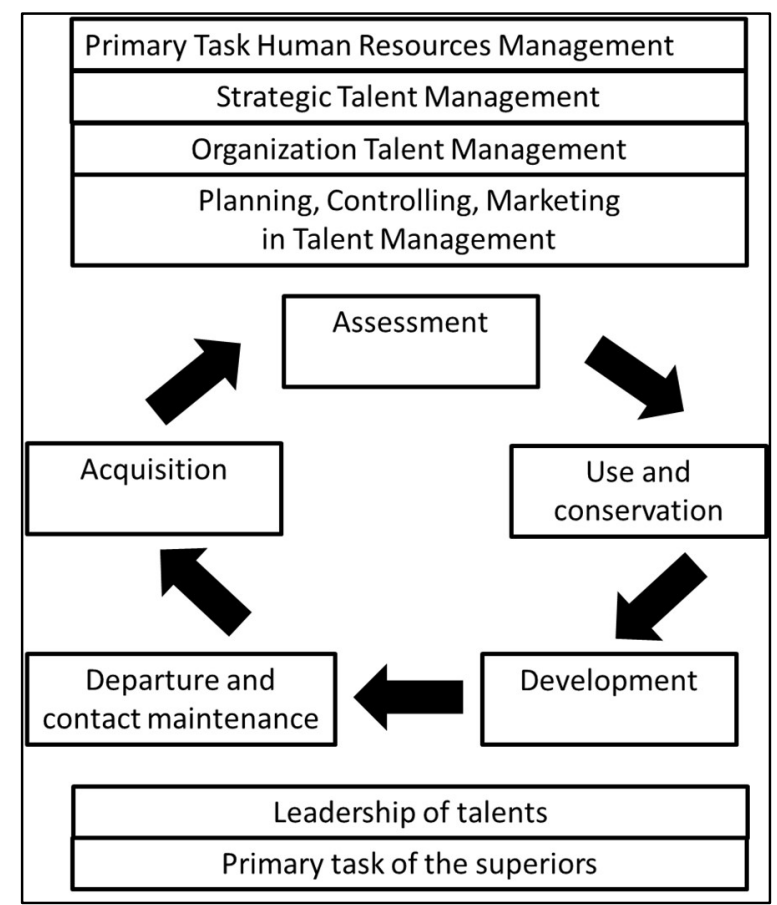

Figure 4 Holistic Talent Management Concept Source: cf. Ritz \& Sinelli, 2010, p. 11 (translated)

As just described in Figure 08, the literature's focus is on the actions that should be implemented in a company, including the importance of the supervisors. However, it must not be forgotten whether the planned measures are attractive to potential talents at all. Ewerlin has investigated, among other things, how the design of talent management in a large company fits the expectations of the talents (cf. Ewerlin, 2013, p. 129)). In the company she examined, talent management focused on developing talents, while retaining talents was lacking. This can lead to well-trained and additionally supported talents, in the event of unfulfilled expectations, under the current conditions, changing employers, which has been considered by the persons involved as a realistic alternative (cf. Ewerlin, 2013, p. 151 ff)). Further research has shown that many large companies are 
concerned about keeping high potentials in their organization (cf. Cappelli \& Keller, 2014, p. 316). Other authors have already noted that the talents' expectations must also be evaluated and observed (cf. Ritz \& Sinelli, 2010, p. 15).

The literature repeatedly mentions the aspect of the employer brand or employer branding. The aim here is to position one's own company in the target groups' perception to be perceived as an attractive employer. It is essential that what one promises is of interest to the target group and can also be adhered to (cf. Burger, 2009, p. 60); Schaper, 2009, p. 30 f; Siemann, 2011, p. 8); Trost, 2012, p. 51 ff; Immerschitt \& Stumpf, 2019, p. 269 ff). Not every measure offered automatically makes the employer an attractive employer. For example, Steckl et al. have investigated whether individual measures prepared by the employer to promote health are appealing to members of Generation $\mathrm{Z}$. Interest in this was in a low double-digit range. Job security, being heard with one's ideas, and meaningful action have a much greater value for this generation (cf. Steckl, Simshäuser, \& Niederberger, 2019, p. 215)).

\subsection{Results for H5: When a company is in an economic crisis, talent management is no longer necessary.}

After analyzing the literature found, it becomes clear that companies have learned from the economic crisis of 2001/02 for the financial crisis that began in 2008. (cf. Sedlacek, 2009 , p. 4). Flexible personnel measures (reducing overtime, short-time work, sabbaticals, part-time work, early retirement, no extension of contracts, hiring stop) have proved their worth to avoid redundancies at first (cf. Armutat, 2009, p. 4; Sedlacek, 2009, p. 6).

If staff still need to be reduced, this is often done at short notice and without extensive preparation (cf. Süßmuth, 2009, p. 64). Companies need to be aware of several risks. On the one hand, the staff's release means that the staff will no longer be available after the crisis. There will be costs to achieve staff reductions, and charges will be incurred again to re-hire new staff for the subsequent upswing. Despite a prevailing crisis, there is always a risk that high-performing personnel will leave the company. After all, despite or especially in times of crisis, competitors can move to recruit high potentials. Finally, a reduction in staff and mishandling of it still poses the problem that this can impact the entire workforce's motivation, which is needed, especially in times of crisis. (cf. Süßmuth, 2009 , p. $64 \mathrm{f}$ ).

Armutat states in his remarks "that strategic, professional personnel work pays off"3 (cf. Armutat, 2009, p. 4). Therefore, every company should know which personnel contributes significantly to the company's success so that resources are available for precisely these personnel to prevent the loss of these high potentials. (cf. Armutat, 2009, p. 5; Sedlacek, 2009, p. 13; Süßmuth, 2009, p. 65).

How personnel can be segmented has already been explained in subchapter 4.1. And it is precisely the segmentation of the personnel staff that is a challenge, as there is often no structure for this to summarize all job descriptions in a meaningful way (cf. Süßmuth, 2009, p. 67).

Besides, the current crisis could give more weight to an already known problem, the "brain drain" (cf. Trost, 2012, p. 11). Haak- Saheem points out in his comments that the Corona pandemic has increased IT equipment in households, making potential workers

\footnotetext{
3 Original Text: „dass sich strategische, professionelle Personalarbeit auszahlt“
} 
more flexible and independent of previously known working conditions ${ }^{4}$ (cf. HaakSaheem, 2020).

To meet the overarching goal even in times of crisis, „securing the company's future viability "5 (Armutat, 2009, p. 7) to do justice, companies need to conduct targeted talent management to continue to have the right staff available after the end of the crisis (cf. Süßmuth, 2009, p. 71).

Although employer attractiveness does not belong to talent management, this aspect must be added to this point. Especially in crisis times, the employer's promise to practice the propagated company values is put to the test. Can the company keep what it has previously promised? At first glance, it seems paradoxical if active support for the staff to be cut is seen as an employee retention measure. But it is precisely these support measures that are considered essential (cf. Sedlacek, 2009, p. $13 \mathrm{ff}$ ).

\section{Discussion}

\subsection{Discussion of the results on H3: The smaller the company, the more likely it is that the owner's position is the key position.}

Various authors have developed different approaches to classifying employees according to the benefits to the company. All approaches have in common that, even if benefits vary, every employee is needed for the company to function. Nevertheless, it is clearly stated that it makes no sense to treat everyone equally from a company's perspective. This approach is a thing of the past (cf. Siemann, 2011, p. 5).

The appropriate allocation of resources, depending on the group of employees, is a challenge because an individual's perceived value with the same performance is likely to be more precious in a micro-enterprise than in a large enterprise. This could be a possible explanation because more employees tend to be referred to as talent in SMEs (cf. Ewerlin, 2013 , p. $56 \mathrm{f}, 87$ ). If an employee fails in an 8-person company, it probably has a different effect on day-to-day operations than if the same employee fails in a 1000-person company. But only on the daily operation.

However, this does not mean every employee in a micro-business automatically holds a critical position for success due to the smaller size. If one accepts the demand that a job can only be regarded as essential of success or as a key function if one can influence the company's strategic orientation, then part of the company's management positions is definitely to be understood as key functions. But not every leadership position meets these requirements. For example, if you compare the head of accounting who, like the owner of a micro-enterprise, can be responsible for eight employees, this position will likely not be a key function. He must ensure that the work to be performed is carried out with the necessary care. This team effort, which he is responsible for, has a supporting role in preparing strategically relevant decisions. However, the executive must decide

\footnotetext{
${ }^{4}$ Additional example: Kremkow found in his study that in Germany, for the most part, scientific staff have only fixed-term employment contracts. In 2005, the share was $80 \%$ of which had risen to $90 \%$ by 2010 and has remained at this level ever since (cf. Kremkow, 2020, p.3 f). In the Netherlands and Norway, the proportion is 40 and 50\% respectively (cf. Kremkow, 2020, p.9). Even if the justification given for this is comprehensible, this practice should be reconsidered based on the most recent experience. There could well be potential for the "brain drain" away from Germany.

5 Original Text: „der Sicherung der Zukunftsfähig des Unternehmens“
} 
which market he wants to be present in, which customers are acquired, whether the company is on a growth course, or whether everything can be stowed with the existing staff.

Based on the literature evaluated, hypothesis 3 will be assessed as accurate.

\subsection{Discussion of the results on $\mathrm{H} 4:$ If talent management is implemented holistically, it can only contribute to its success.}

In the literature evaluated, no approach would have been limited to only one function of talent management. In the end, there was always a sequence in which the functions of talent management - "identify and win", "assessment and insertion", "developing", and "motivating and binding" - were similarly coordinated. However, it has always been made clear that only a holistic approach can be successful.

Employer attractiveness is also mentioned as an essential aspect, without being a part of talent management. When employees can choose a job, entrepreneurs will have an advantage in the labor market, who have the right image that can be "promoted" not only in advertising but also in everyday life by employees.

But what makes a company attractive? A company is attractive when the expectations of the (potential) employees are met. However, it is necessary to find out in advance what the respective target group expects.

This summary alone clearly shows once again that talent management is more than just the development of employees.

Based on the literature evaluated, hypothesis 4 will be assessed as accurate.

\subsection{Discussion of the results on H5: When a company is in an economic crisis, talent management is no longer necessary.}

The literature results show that a forward-looking approach to one's staff, with one's talents, is vital, even, or especially at times of crisis. If the duration of the crisis forces the company to reduce its workforce, the employees to be made redundant should, if possible, not accompany vital functions or have special qualifications in order not to jeopardize the subsequent upswing. To make these decisions, one must be aware of its employees' different qualities and the company's critical functions. This is only possible if you have done the appropriate assessment in advance. This is also the prerequisite for being able to generate an advantage for itself from a crisis. If competitors must exhibit personnel, talents, this is where the future can be strengthened for the own company. If you have the funds, you can acquire staff (talents) who may be released in times of crisis. However, to do this, it must be clear who is needed for which job to tackle a new project.

Talent management must also be able to adapt to external changes that one has not thought of before. A crisis can create a changing environment. In the current situation is the keyword "virtual workplace." To continue to work in the crisis, the home office solution has the disadvantage that this form of work could motivate one's employees to take on another job that would not have been possible in a world of physical jobs. This change must be reconsidered in the functions "identify and win" and "motivation and binding." 
SMEs must be aware of the danger they face in times of crisis. Due to the smaller size, the loss of a high potential has quite different effects than the case in a large company.

Based on the literature evaluated, hypothesis 5 must be discarded.

\section{Conclusion}

With the help of qualified literature analysis, this article should clarify how effective and efficient talent management is based on periods of economic recovery and economic crisis. To answer this question, the following hypotheses have been formulated:

- H3) The smaller an enterprise, the more it is true that the owner's position is the key position.

- H4) If talent management is implemented holistically, it can only contribute to the company's success.

- H5) When a company is in an economic crisis, talent management is no longer necessary.

H3 and H4 could be confirmed, whereas H5 had to be discarded.

First, it must be clear which positions in the company determine its success and what prerequisites potential employees must have to fill these positions in total. The company should be aware of which employee is essential for the organization and is easier to replace. This gives the company a basis for which employees need to be required and promoted more and which less.

Second, talent management does not stand alone. The goals are to be derived from the corporate strategy and should be implemented holistically through the functions of talent management, "Identify and Win", "Assessment and Insertion", "Develop" and "Motivating and Binding". In all considerations, the reflections and expectations of the talents must not be forgotten. There is no point in creating an offer that does not meet the needs or expectations.

Finally, the aspect of the employer's brand must be listed. Even if this is not originally part of talent management, it is a prerequisite for being perceived positively by the employees. There is no point in, for example, promising measures that are of no importance to the required staff or that are feasible.

Third, the findings are valid both in economic recovery times and in crisis times and will help survive the latter better. It is essential that Talent Management is in place and prepared for a crisis before a crisis is rising. When the crisis has arrived, talent management must be able to drive forward internal measures while taking account of changes in the environment to respond.

Based on the considerations and investigations carried out, further studies should examine talent management in the brewing industry. Both the owners' and potential talents' perspectives need to be prepared.

A press release of the German Brewers' Association of 01.04.2020 shows that dealing with staff is an explosive topic. A member survey conducted by the German Brewers 
Association showed that $18 \%$ of the members expect staff redundancies due to the Corona crisis (cf. Huhnholz, 2020).

\section{REFERENCES}

ARMUTAT, S. (2009). Personalabbau im Rahmen des nachhaltigen Belegschaftsmanagements PraxisPapier 8/2009. Düsseldorf: Deutsche Gesellschaft für Personalführung e.V. .

BENDER, M. (2021). TALENT MANAGEMENT IN GERMAN SMALL AND MEDIUM-SIZED COMPANIES (SMES) PART I-A CRITICAL ANALYSIS. Von bulletinmonumental.com: http://bulletinmonumental.com/gallery/15-jan2021.pdf abgerufen 01.02.2021

Bildungsserver. (2020). Schuladressverzeichnisse der Statistischen Landesämter. Von deutscher bildungsserver:

https://www.bildungsserver.de/Schuladressverzeichnisse-der-StatistischenLandesaemter-11341-de.html abgerufen 13.10.2020

BOUDREAU, J., \& Ramstad, P. (2005). Talentship and the new paradigma for human resources management: from professional practice to strategic talent decision science. Human resource planning (Band 28, Heft 2), S. 17 - 26.

BRAUERBUND, D. (2020). Betriebene Braustätten nach Bundesländern. Von Deutscher Brauerbund: https://www.brauerbund.de/download/Archiv/PDF/statistiken/2018_Braust\%C3\%A4tten.pdf abgerufen 16.10 .2020

Bundesagentur. (2020). Schule, Ausbildung und Studium in Deutschland. Von Bundesagentur für Arbeit: https://www.arbeitsagentur.de/fuer-menschen-ausdem-ausland/schule-ausbildung-studium-indeutschland\#: :text=Schule\%2C\%20Ausbildung\%20und\%20Studium\%20in\%2 0Deutschland\%201\%20Schule.,Fachhochschulreife\%20oder\%20einen\%20gleic hwertigen\%20Abschluss.\%20More\%20i abgerufen 14.10.2020

BURGER, A. (2009). Talentmanagement zwischen Ideal und Wirklichkeit. In A. Weitz, Talentmanagement im Mittelstand (S. 55 bis 67). Lengerich: Pabst Science Publishers.

CAPPELLI, P., \& Keller, J. (2014). Talent Management: Conceptual Approaches and Practical Challenges. The Annual Review of Organizational Psychology and Organizational Behavior, S. 306 - 325.

EWERLIN, D. (2013). Talentmanagement im nationalen und internationalen KontextEmpirische Analysen vor dem Hintergrund des Situativen Ansatzes. Düsseldorf: Heinrich Heine Universität. 
FELD, L. P., Truger, A., \& Wieland, V. (2020). Die gesamtwirtschaftliche Lage angesichts der Corona-Pandemie. Von ECONSTOR: https://www.econstor.eu/handle/10419/215776 abgerufen 15.01.2021

HAAK-SAHEEM, W. (2020). Talent management in Covid-19 crisis: how Dubai manages and sustains its global talent pool. Von Springer.com: https://link.springer.com/content/pdf/10.1057/s41291-020-00120-4.pdf abgerufen 17.03.2021

HORN, G. A. (2020). Konjunkturphasen. Von Gabler Wirtschaftslexikon: https://wirtschaftslexikon.gabler.de/definition/konjunkturphasen38767/version-262188 abgerufen 15.01.2021

HUHNHOLZ, M.-O. (2020). P R E S S E M I T T E I L U N G: DBB-Umfrage zu den Auswirkungen der Corona-Pandemie auf die deutsche Brauwirtschaft: Kurzarbeit, Umsatzeinbrüche und Versorgungsengpässe. Von www.brauer-bund.de: https://www.brauerbund.de/download/Textdatenbank/2020/200401\%20DBB-PM\%20DBBUmfrage\%20Auswirkungen\%20CoronaPandemie\%20deutsche\%20Brauwirtschaft\%20Kurzarbeit\%20Umsatzeinbr\%C3 \%BCche\%20und\%20Versorgungsengp\%C3\%A4sse.pdf abgerufen 10.04.2020

IMMERSCHITT, W., \& Stumpf, M. (2019). Employer Branding für KMU. Wiesbaden: Springer Gabler.

IOST, O., \& Iost, K. (2020). Brauwesen und Getränketechnologie. Von Studis Online: https://www.studis-online.de/Studiengaenge/Brauwesen-undGetraenketechnologie/ abgerufen 15.10.2020

IOST, O., \& Iost, K. (2020). Studiengänge in Deutschland. Von Studis Online Die schlauen Seiten rund ums Studium: https://www.studis-online.de/Studiengaenge/ abgerufen 13.10.2020

KREMPKOW, R. (2020). Die Beschäftigungsbedingungen des wissenschaftlichen Nachwuchses in Deutschland: Empirische Ergebnisse. Von ResearchGate:https://www.researchgate.net/profile/ReneKrempkow/publication/343500765_Die_Beschaftigungsbedingungen_des_wisse nschaftlichen_Nachwuchses_in_Deutschland_Empirische_Ergebnisse/links/5fa2b c5a458515157be96b8f/Die-Beschaeftigungsbedingungen-deswissenschaftlichen-Nachwuchses-in-Deutschland-Empirische-Ergebnisse.pdf abgerufen 17.03.2021

MAYRING, P. (2015). Qualitative Inhaltsanalyse - Grundlage und Techniken, 12., überarbeitete Auflage. Weinheim und Basel: Beltz Verlag. 
RIDDER, H. G. (2001). Strategisches Personalmanagement: Architektur und Steuerungsprinzipien. In: Becker, Manfred und Schwarz, Volker (Hg.)- Theorie und Praxis der Personalentwicklung. Aktuelle Beiträge aus Wissenschaft und Praxis. S.92-111. München und Mering: Rainer Hampp Verlag.

RITZ, A., \& Sinelli, P. (2010). Talent Management - Überblick und konzeptionelle Grundlagen. In: Ritz, A. \& Thom, N.: Talent-Management. Wiesbaden, S. 3-24.

SCHAPER, N. (2009). Wozu benötigt die Personalpraxis Talentmanagementansätze. In A. Weitz, Talentmanagement im Mittelstand (S. 13 - 35). Lengerich: Pabst Science Publishers.

SEDLACEK, B. (2009). Personalmanagement in der Wirtschaftskrise Befragungsergebnisse PraxisPapier 3/2009. Düsseldorf: Deutsche Gesellschaft für Personalführung e.V. .

SEIL, E., \& Emmler, H. (2020). Die Folgen von Corona: Eine Auswertung regionaler Daten. Von ECONSTOR: https://www.econstor.eu/bitstream/10419/224251/1/wsipb43.pdf 06.10.2020 abgerufen

SIEMANN, C. (12 Sonderheft 2011). Gut gerüstet für Schwankungen. Personalwirtschaft, S. 4 - 9.

STATISTA. (2020). Branchenübersicht - Alle Branchen und zugehörige Unterbranchen. Von STATISTA: https://de.statista.com/statistik/kategorien/ abgerufen 12.10 .2020

STATISTA. (2020). Unternehmen in Deutschland: Anzahl der rechtlichen Einheiten* in Deutschland nach Beschäftigtengrößenklassen im Jahr 2018. Von Unternehmen in Deutschland: Anzahl der rechtlichen Einheiten* in Deutschland nach Beschäftigtengrößenklassen im Jahr 2018: https://de.statista.com/statistik/daten/studie/1929/umfrage/unternehmennach-beschaeftigtengroessenklassen/ abgerufen 03.06.2020

STECKL, M., Simshäuser, U., \& Niederberger, M. (2019). Arbeitgeberattraktivität aus Sicht der Generation Z. Prävention und Gesundheitsförderung, H.3, S. 212 bis 217.

SÜßMUTH, B. (2009). Welche Maßnahmen für welche Mitarbeitergruppen?: Talentmanagement in der Rezession. Personalführung: für alle, die Personalverantwortung tragen- 42, H.8, S. 64 - 71.

TAGEsschau.de. (2020). Szenarien für die Konjunkturerholung. Von tagesschau.de: https://www.tagesschau.de/wirtschaft/boerse/szenarien-konjunkturerholung101.html abgerufen 25.05.2020

TROST, A. (2012). Talent Relationship Management - Personalgewinnung in Zeiten des Fachkräftemangels. Heidelberg: Springer Verlag Berlin. 
TROST, A. (2014). Talentmanagement im Mittelstand. In Schwuchow, Personalentwicklung: Themen, Trends, Best Practises (S. 257 - 268).

WEITZ, A. (2009). Talentmanagement zur Generierung von Führungsnachwuchskräften im Mittelstand. In A. Weitz, Talentmanagement im Mittelstand (S. 68 - 84). Lengerich: Pabst Science Publishers.

WHYSALL, Z., Owtram, M., \& Brittain, S. (2019). The new talent management challenges of Industry 4.0. Von Emerald Insight: https://pustakasarawak.com/eknowbase/attachments/1585622063.pdf abgerufen 17.03.2021

ZIEGLER, P., Hefler, G., Markowitsch, J., \& Lehner, K. (2010). Talente Management in ausgewählten niederösterreichischen Betrieben: Zentrale Ergebnisse einer Studie im Auftrag des AMS Niederösterreich. Wien: Arbeitsmarktservice Niederösterreich Landesgeschäftsstell Systemmanagement und Arbeitsmarktinformation Marcus Ambrosch. 